49. Siegel, D. S. Assessing the impact of organizational practices on the relative productivity of university technology transfer offices: an exploratory study [Text] / D. S. Siegel, D. Waldman, A. Link // Research Policy. - 2003. - № 32 (1). - P. 27-48.

50. Siegel, D. S. Assessing the impact of university science-parks on research productivity: exploratory firm-level evidence from the United Kingdom [Text] / D. S. Siegel, P. Westhead, M. Wright // International J. of Industrial Organization. 2003. - № 21. - P. 1357-1369.

51. Siegel, D. S. Improving the effectiveness of commercial knowledge transfers from universities to firms [Text] / D. S. Siegel, D. Waldman, A. Link // J. of High Technology Management Research. - 2003. - № 14. - P. 111-133.

52. United Nations Framework Conventionon Climate Change. Recommendations on Future Financing Options for Enhancing the Development, Deployment, Diffusion and Transfer of Technologies Under the Convention. - 2009. - Subsidiary Body for Science and Technological Advice. - Bonn, United Nations. FCCC/SB/2009/2 [Electronic resource]. - Access mode: unfccc.int/resource/docs/2009/sb/eng/02.pdf. - Title from the screen.

53. Wang, B. Can CDM bring technology transfer to China? - An empirical study of technology transfer in China's CDM projects [Text] / B.Wang // Energy Policy. 2010. - № 38(5). - P. 2572-2585.

54. Ward, V. Developing a framework for transferring knowledge into action: a thematic analysis of the literature [Text] / V. Ward, A. House, S. Hamer // J. of health services research \& policy. - 2009. - № 14 (3). - P. 156-164.

55. Weckowska, D. M. Learning in university technology transfer offices: transactions-focused and relations-focused approaches to commercialization of academic research [Text] / D. M. Weckowska // Technovation. - 2015. - № 41-42 . - P. 62-74.

56. Wolfe, D.A. Innovation and research funding: the role of government support [Text] / D. A. Wolfe // Taking Public Universities Seriously / ed.: F. Iacobucci, C. Tuohy.- Toronto, 2005. - P. 316-340.

57. Youtie, J. Building an innovation hub: A case study of the transformation of university roles in regional technological and economic development [Text] / J. Youtie, P. Shapira // Research Policy. - 2008. - № 37. - P. 1188-1204.

Надійшла до редколегї 15.11.15

\title{
УДК 378.011.3
}

\author{
М. О. Кальніцька
}

Дніпропетровський національний університет імені Олеся Гончара, Україна

\section{ВПЛИВ ОРГАНІЗАЦЙНОЇ КУЛЬТУРИ НА ІННОВАЦЙНИЙ ПОТЕНЦІАЛ ПІДПРИЕМСТВА}

Розкрито фундаментальні чинники та явища, які безпосередньо впливають на організаційну культуру підприсмства, надано їх розгорнуту характеристику. У межах проблематики окремо описано різні групи факторів: первинні та вторинні, зовнішнього й внутрішнього середовища. На основі проведеного аналізу визначено вплив кожного фактора на ефективність функціонування організаційної культури підприсмства. Визначено структуру

(C) Кальніцька М.O., 2015 
інноваційного потенціалу підприємства і її взаємозв'язок із базовими елементами та факторами організаційної культури.

Ключові слова: організаційна культура, інноваційний потенціал, організація, вплив, цінності, філософія, підприємство.

Раскрыты фундаментальные факторы и явления, которые непосредственно влияют на организационную культуру предприятия, предоставлена их развернутая характеристика. В рамках проблематики отдельно описаны различные группы факторов: первичные и вторичные, внешней и внутренней среды. На основе проведенного анализа определено влияние каждого фактора на эффективность функционирования организационной культуры на предприятии. Определена структура инновационного потенциала и выявлено место организационной культуры в нем.

Ключевые слова: организационная культура, инновационный потенциал, организация, влияние, ценности, философия, предприятие.

Fundamental factors, which influence on organizational culture of the enterprise, are exposed, provided their characteristic. Various groups of factors are separately described: primary and secondary, external and internal environment. On the basis of the analysis is defined the influence of each factor on efficiency of functioning of organizational culture at the enterprise. The structure of innovational potential and organizational culture was determined and compared. The article contains conclusions about common base of organizational culture and innovational potential. enterprise.

Key words: organizational culture, innovational potential, influence, organization, values, philosophy,

\section{Вступ}

Постановка проблеми. Кожна організація як соціально-економічна система зазнає впливу факторів зовнішнього та внутрішнього середовища, у свою чергу, організаційна культура (ОК) підприємства - продукт взаємозв'язку зовнішнього та внутрішнього середовища підприємства, отже, будь-який їх вплив визначатиме подальше становлення і розвиток ОК.

Чинники як зовнішнього, так і внутрішнього середовища можуть мати позитивні або негативні тенденції до зміни. У випадку негативного впливу факторів ОК керівникам підприємства необхідно реагувати на зміни для збереження цілісності та функціональності системи ОК підприємства. Таким чином, проблемним є питання виявлення впливу факторів, що дозволить прогнозувати позитивну або негативну тенденцію зміни організаційної структури, що в результаті визначить можливість підвищення інноваційного потенціалу підприємства.

Аналіз досліджень і публікацій. Проблемам ОК у різних векторних напрямах присвячено роботи як вітчизняних, так і зарубіжних дослідників. Спектр питань вивчення досить широкий. Наприклад, у працях Т. Діла та А. Кеннеді [1] цінності, ділове середовище, герої, обряди, системи культурної комунікації та ритуали - це головні елементи організаційної культури. Е. Шейн [18] виділяє окремо базові уявлення, проголошені цінності та артефакти. У сучасніших працях, крім розкриття сутності поняття «організаційна культура», описано її використання як специфічного інструменту для впровадження та реалізації організаційних змін.

Питання визначення факторів, що впливають на стан ОК, розглянуто у працях Е. Шейна [18], Р. Льюіса [13]. Вивчаючи роботи вітчизняних науковців, можна виділити дослідження В.В Усачової [16], яка визначила особливості ОК у транзитивній економіці. У працях Г.М. Захарчин [6] та В.В. Кириченко [9] було визначено механізми формування ОК на промислових підприємствах. Фактори ОК на підприємствах харчової промисловості дослідила О.В. Харчишина [17] Детермінанти розвитку ОК підприємств сфери освіти проаналізовано в роботі

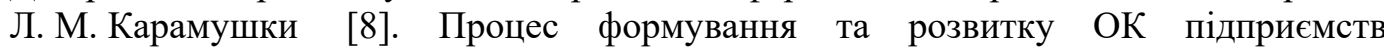


туристичного бізнесу проаналізовано у працях О.П. Крупського [11]. Дослідженню сутності інноваційного потенціалу підприємства присвячено низку робіт закордонних авторів, таких як П. Друкер [5], Й. Шумпетер [2], та вітчизняних дослідників - В. І. Ландика [12], Н.С. Краснокутської [10] та ін. Але, незважаючи на широке коло досліджених, визначених та проаналізованих явищ, умов i факторів, ця тема ще не достатньо вивчена, а отже, потребує подальшого вивчення, аналізу в динаміці та уточнення факторів впливу.

Постановка завдання. Мета написання статті полягає у вивченні впливу факторів зовнішнього та внутрішнього середовища організації на складники ОК й інноваційний потенціал підприємства. Методи дослідження - аналіз та синтез, системний підхід.

Виклад основного матеріалу. Поняття «організація» трактують як деяку групу людей, пов'язаних схожими інтересами, об'єднаних для досягнення спільних цілей [3]. Будь-яка організація у процесі формування та розвитку набуває організаційної культури, яка, у свою чергу, продовжує функціонувати в організації. Базою для ОК є цінності iї керівної структури та співробітників, які утворюють систему всередині організації.

За Е. Шейном, ОК - це упорядкований комплекс припущень, винаходів, утворений групою людей усередині організації для набуття навичок реагування на проблеми зовнішньої адаптації й внутрішньої інтеграції. Мова йде про стабільне функціонування цього комплексу для його подальшої передачі новим співробітникам. Тоді даний комплекс можна було б сприймати як правильний спосіб мислення стосовно внутрішніх питань організації [18, с.31-32].

Культура організації - це укомплектована складна композиція елементів, які часто не мають чітких формулювань, але можуть бездоказово сприйматися колективом організації. Здебільшого культуру організації визнають певною філософією всередині компанії, ідеологією управління, яка містить ціннісні орієнтації, очікування, вірування, розпорядження й норми, що становлять основу відносин як усередині колективу організації, так і за його межами.

Отже, вважатимемо, що організаційна культура - це модель ключових цінностей, вірувань і норм, спільних для всіх членів колективу, які передають новим членам колективу як істинні та єдино правильні. Це своєрідна аура організації, що об’єднує всі підрозділи й всіх членів колективу в єдиний організм, який злагоджено функціонує за визначеними правилами та процедурами й по суті спрямований на досягнення спільної мети.

Крім дефініції «організаційна культура» науковці та публіцисти застосовують поняття «корпоративна культура», «культура організації». Усі вони мають спільне смислове навантаження, а отже, групу наведених визначень можна вважати синонімічним рядом [4].

Узагалі під поняттям «потенціал» прийнято вважати певну можливість, тобто можливість організації найефективніше реалізувати те чи інше функціональне завдання за максимального використання наявних ресурсів. Виходячи 3 цього інноваційним потенціалом прийнято вважати економічні можливості організації 3 ефективного залучення новітніх технологій у функціональну діяльність підприємства [12].

Для розкриття проблематики статті детально структуруємо поняття та визначимо елементи, які ОК містить, також визначимо структуру інноваційного потенціалу, його складники. У загальному вигляді ОК можна подати як комплекс із шести базових елементів (рис.1). 


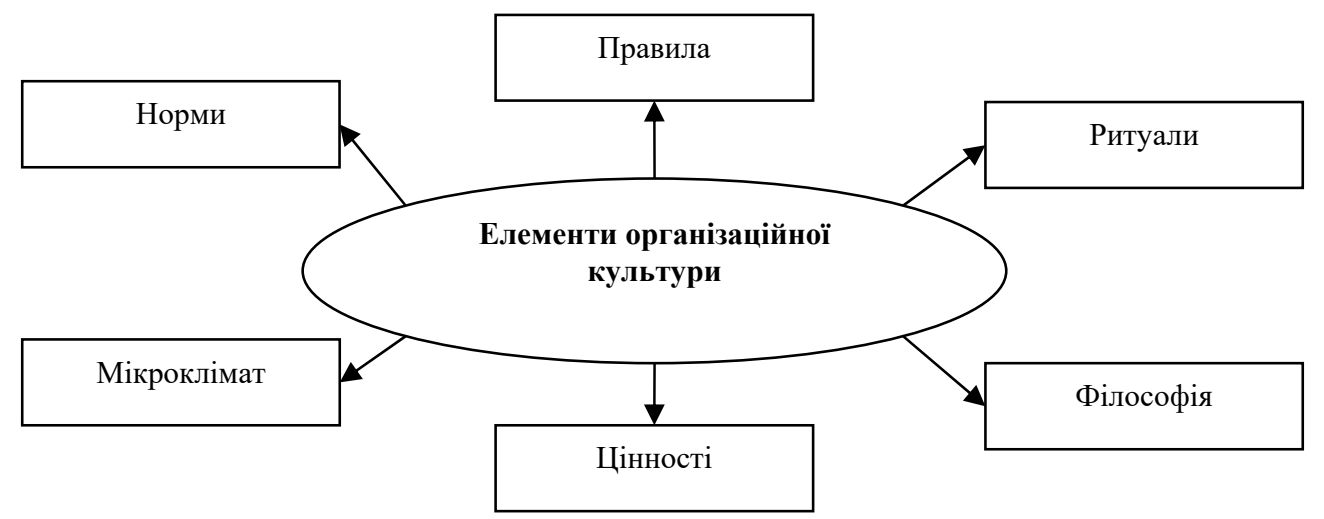

Рис. 1. Базові складники організаційної культури*

*Розробив автор на основі $[18 ; 19]$.

Норми та правила задають формалізований темп і спосіб співпраці, визначають принципи взаємовідносин в організації. Найчастіше їх застосовують у розпорядженнях та посадових інструкціях, під час проведення певних церемоній i ритуалів, використання професійного сленгу, становлення організаційних символів. Мікроклімат організації - це своєрідне соціально-психологічне виявлення міжособистісних стосунків в організації, що проявляється в сукупності умов, які можуть сприяти або перешкоджати іï ефективному функціонуванню. Цінності організація формує ще на стадії свого становлення, проте у процесі функціонування може їх корегувати або змінювати відповідно до своїх цілей. Основний сенс створення, існування та функціонування організації задає певна філософія. Це поняття стосується форм i методів формування стосунків із робітниками організації та клієнтами.

Наведені вище складники утворюють систему лише за умови цілісності та наявності більшості з них. Тобто неможливо створити ОК на основі норм і правил або лише за наявності низки цілей.

Основні елементи інноваційного потенціалу подано нижче (рис. 2).

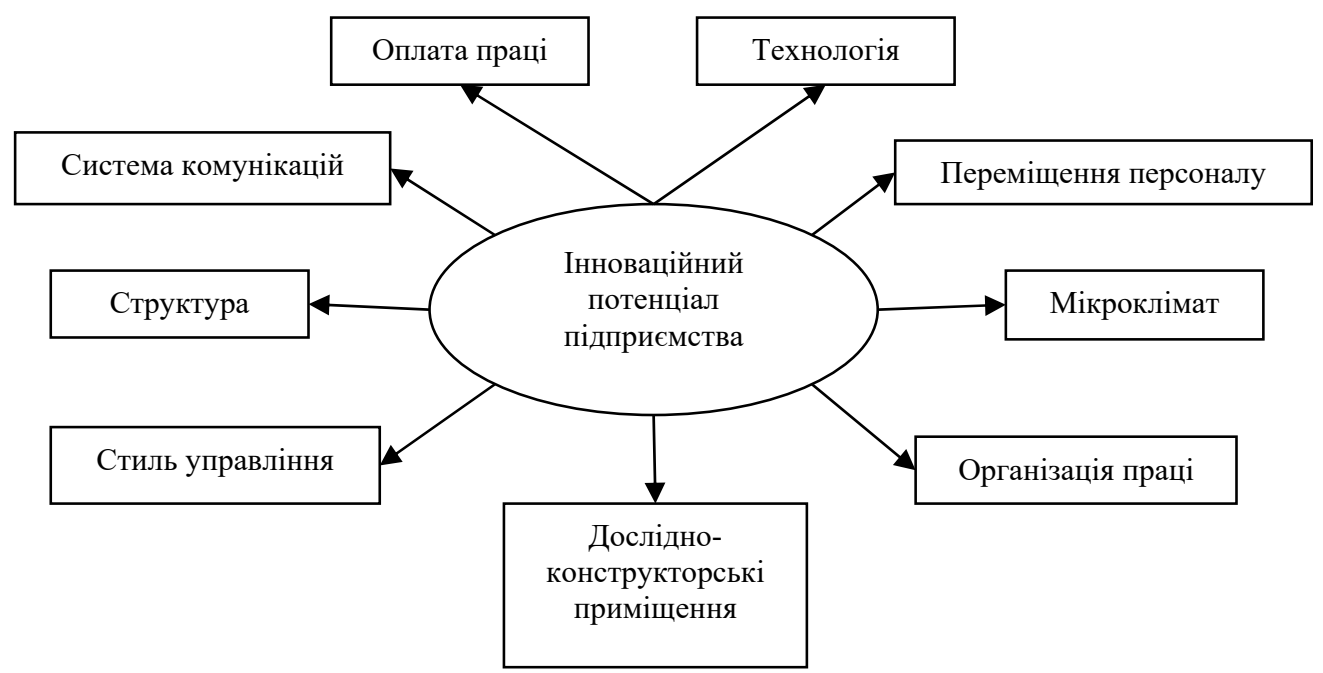

Рис. 2. Структура інноваційного потенціалу підприємства*

${ }^{*}$ Розробив автор на основі [18, с. 5]. 
Інноваційно орієнтовані підприємства включають дев'ять базових елементів, які ми умовно об’єднаємо у дві групи - пов'язані з виробничими процесами підприємства (структура, наявність інноваційних лабораторій, технології, організація праці, переміщення персоналу, оплата праці) та пов’язані з управлінням (стиль управління, система комунікацій, мікроклімат). Структура організації має бути адаптивна, лінійно-функціональна, 3 елементами проектних утворень; дослідно-конструкторські приміщення повинні бути універсального типу 3 можливістю зміни або компонування; технології - гнучкі, адаптивні, автоматизовані робочі модулі - 3 високоорганізованою транспортною системою; організація праці повинна бути командною, із вільним вибором робочого часу для ефективнішого його використання; переміщення персоналу - гнучкі, мають відбуватися як горизонтально, так i вертикально (із можливістю утворення проектних груп); оплата праці - погодинно-преміальна. Стиль управління повинен передбачати високий ступінь делегування повноважень, залучення персоналу до процесу прийняття рішень, а система комунікацій - налагоджений процес регулярного інформування співробітників про головні організаційні аспекти функціонування, мікроклімат - стимулювання персоналу до творчого розвитку та підвищення інноваційної активності.

Отже, у результаті порівняння структур ОК та інноваційного потенціалу виявлено спільні та взаємозалежні елементи. Глибший аналіз проведемо за допомогою визначення головних факторів ОК.

Е. Шейн описує функціонування первинних i вторинних факторів, під впливом яких відбувається формування й зміна ОК. Відповідно до його концепції можна виділити п’ять первинних факторів:

1. Реакція керівника на критичні проблеми організації. Будь-яка проблема спричиняє занепокоєння у колективі, тому модель поведінки керівника, спрямована на вихід із кризи, формує систему цінностей та вірувань, які стають реальними для співробітників.

2. Критерії для заохочення співробітників. Учасники колективу, усвідомлюючи перспективу нагородження або покарання, формують для себе уявлення про реальні та недопустимі моменти в роботі організації, і при цьому самі закріплюють культуру організації.

3. Точка концентрації уваги керівника. Зазвичай апарат управління загострює увагу на принципових або необхідних питаннях, які важливо вирішити. Точки концентрації уваги керівника обумовлюють цілі організації.

4. Критерії для вибору, призначення та просування, звільнення працівників. Дані критерії сформовано на основі філософії організації в цілому, тому суттєво впливають на розуміння працівником ціннісних орієнтацій компанії.

5. Стиль поведінки керівника та його ставлення до роботи. Оскільки керівник для організації - це публічна особа, яка задає вектор поведінки, то він є прикладом для підлеглих. Працівники дублюють стиль поведінки та ставлення до роботи, формуючи таким чином стійкі норми [18, с. 197-208].

Інша група, відповідно до теорії Е. Шейна, складається з таких факторів:

1. Передача інформації та організаційні процедури. Кожен співробітник веде нормативну документацію, звітуючи перед керівництвом. Це створює певний клімат в організації, який обумовлює поведінку іiі членів.

2. Структура організації. Залежно від того, які функції виконують співробітники у межах підрозділів, формується їх уявлення про ступінь довіри у керівництва, заохочення ініціативності членів колективу. 
3. Дизайн та оформлення приміщень. Дизайн фізичного простору в цілому повинен бути виконаний у витриманому стилі, який формує загальне уявлення співробітників та клієнтів про організацію, місце кожного з них у іiі межах.

4. Міфи та історії. Будь-яка організація має історію, яку систематично передають у разі оновлення колективу, вона сприяє збереженню духу організації у часі.

5. Положення щодо філософії та сенсу існування організації. Сформована філософія та цілі організації, набір цінностей і заповідей необхідно доводити до співробітників, це сприяє формуванню культури організації та адекватної місії [18, с. 209-214].

Кожен із десяти факторів ОК потребує застосування певних методів i прийомів, які сприяють сталому функціонуванню культури організації.

Крім вищеописаних факторів впливу на організаційну культуру окремо виділяють інші чинники. Ці явища й процеси розподіляють на два структуровані блоки, кожен із яких включає набір чинників сфери свого впливу. Як відомо, кожна функціонуюча організація має або навколо себе, або всередині певне середовище, що являє собою сукупність обставин і факторів, які впливають на прийняття рішень. Реально функціонуюча в часі організація постійно зазнає впливу елементів як зовнішнього, так і внутрішнього середовища.

Зовнішнє середовище організації - це комплексна елементна структура, яка не входить до складу підприємства, проте певним чином на нього впливає. Чинниками зовнішнього середовища називають явища та процеси зовнішнього оточення організації, вплив яких відображається на функціонуванні корпоративної культури:

1. Ділові партнери - це важливий елемент оточення організації, оскільки кількість партнерів та їх репутація впливають на загальний імідж організації, а отже, i на іiі організаційну культуру.

2. Акціонери й власники задають напрям формування організаційної культури, значну увагу приділяють думці акціонерів та власників, оскільки саме їх погляди вважають фундаментальними для формування цілей і цінностей.

3. Національна культура та менталітет - впливовий фактор, тому що він проявляється під час організації та ведення багатонаціонального бізнесу в різних країнах, де кожна нація та ментальність співробітників мають значні відмінності. Для ефективного функціонування організації в різних державах необхідно формувати іiі культуру з урахуванням цих відмінностей, таким чином колектив підприємства адекватно сприйматиме філософію організації, яка буде зрозуміла кожному працівникові.

4. Конкуренти на сьогоднішній день - майже невід'ємний аспект роботи організації, їх вивчення та аналіз допомагають виявити головні конкурентні переваги, на які акцентують увагу під час функціонування культури організації.

5. Законодавчі акти формують нормативну базу ОК у межах чинного законодавства країни, на території якої здійснює діяльність організація.

6. Інвестори вкладають інвестиції в організацію, яка має незаплямовану репутацію, що викликає довіру. Сприятливий інвестиційний клімат у компанії допомагає формувати функціональну організаційну культуру. Для будь-якої організації актуальні питання покращення інвестиційного клімату.

7. Науково-технічний прогрес допомагає підвищити рівень розвитку організаційної культури, оскільки сучасна ситуація свідчить про недостатню розвиненість культури організації. Така ситуація склалася у зв'язку із 
застосуванням застарілих методів організації роботи персоналу, виробництва, менеджменту.

8. Міжнародна економічна, політична та соціальна ситуація впливає на культуру організації через створення загальних напрямів і тенденцій розвитку організації. Крім того, цей фактор допомагає встановити сучасні загальнолюдські цінності, які враховують у процесі функціонування організаційної культури.

9. Внутрішня економічна, політична та соціальна ситуація визначають специфіку роботи організації, окреслюють загальний рівень життя працівників, основні ідеологічні установки, що впливає на культуру організації, формуючи ціннісні орієнтації, певний ступінь соціального захисту учасників колективу та відповідальність організації перед колективом [4].

Блок факторів зовнішнього середовища наведено нижче (рис. 3).

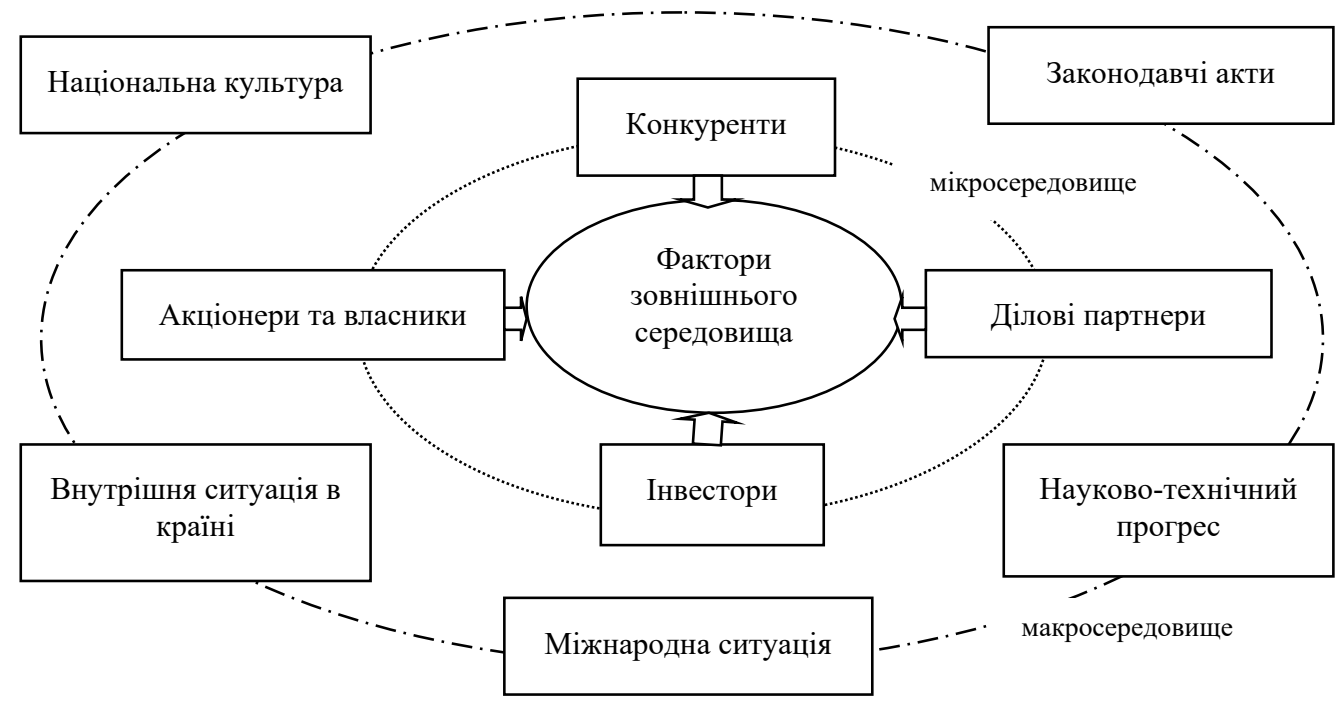

Рис. 3. Фактори зовнішнього середовища

* Розробив автор на основі [4, с. 19].

Визначення факторів зовнішнього середовища потребує проведення аналізу внутрішнього поля діяльності організації, яке також може функціонально змінювати елементи організаційної культури. У загальному визначенні внутрішнє середовище - це джерело життєвого ресурсу організації, іiі потенціал, який створює умови для існування та функціонування в певному часовому континуумі. У випадку незабезпечення або недостатнього забезпечення організації внутрішніми ресурсами для їі функціонування вона може припинити своє існування (ліквідація, банкрутство).

Факторами внутрішнього середовища називають набір внутрішньоорганізаційних характеристик, які впливають на організаційну культуру (рис. 4.) [4]. 


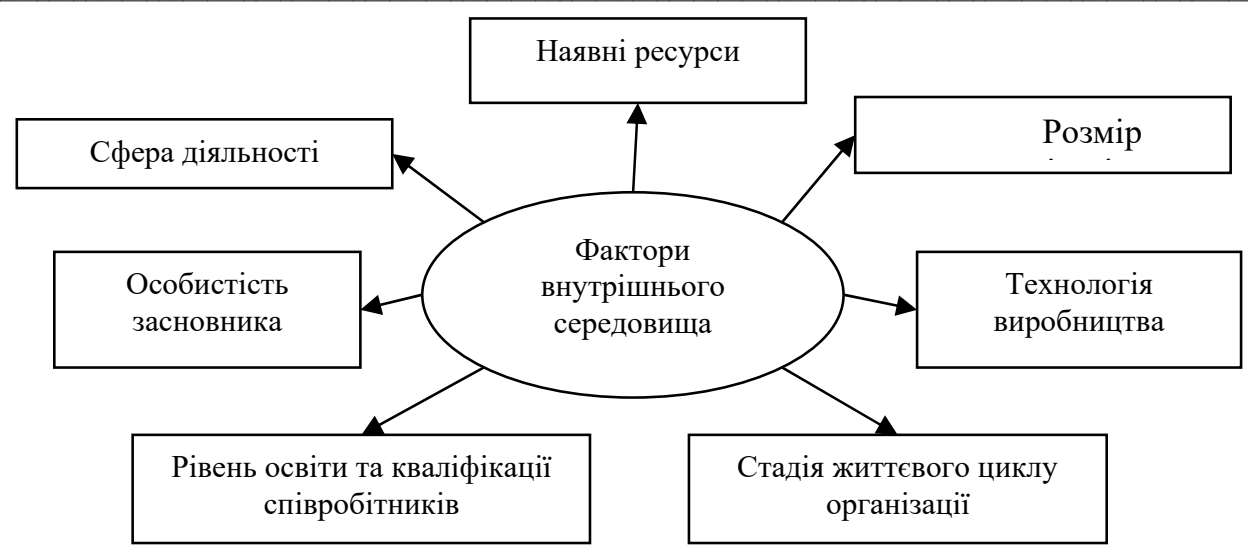

Рис. 4. Фактори внутрішнього середовища*

* Розробив автор на основі [4; 14].

1. Особистість засновника впливає на організаційну культуру таким чином, що весь комплекс своїх переконань, світогляд та ідеали він виражає в культурі організації, передає як ідеологію кожному працівнику різних підрозділів. На думку Е. Шейна [18], саме засновник організації має фундаментальний вплив на концепцію організаційної культури, уводячи суб’єктивні ціннісні погляди як основу для побудови ОК.

2. Рівень освіти і кваліфікація співробітників проявляються в тому, як саме учасник колективу сприймає цінності та філософію організації, наскільки він ініціативний і відкритий для творчої роботи. Визначивши склад колективу, можна підібрати правильні методи навчання для підвищення кваліфікації персоналу.

3. Розмір організації впливає на формування іiі культури за допомогою визначення пріоритетних для неї цілей. Залежно від розміру підприємства на етапі його формування визначають місію, яка обумовлює ціннісні орієнтації організації.

4. Стадія життєвого циклу організації закріплює певну культуру, зі зміною стадії зазнає змін і ОК. За законами циклічності кожне підприємство проходить такі стадії: створення, зростання, юність, зрілість і старіння, що супроводжується спадом іiі ділової активності та прибутковості й потребує оновлення.

5. Сфера діяльності організації також обов'язково коригує ціннісні орієнтації та загальну філософію організаційної культури, оскільки кожна сфера має специфічні відмінності, які необхідно враховувати. Ціннісні погляди організації, що працює в галузі надання певних послуг, відрізняються від поглядів підприємства, яке займається виробництвом, оскільки перша фокусує увагу на задоволенні потреб споживачів, а друга - на виробленні якісної товарної продукції.

6. Технологія виробництва задає напрям застосування організаційної культури. Таким чином, застосовуючи сучасні технології, можна створити більш гнучку й пристосовану до вимог зовнішнього середовища організаційну культуру, покращити умови праці, провести дослідження та розробки, приділити більше уваги нормам екологічної безпеки.

7. Наявні ресурси забезпечують процес формування та розвитку організаційної культури. Їх якісний і кількісний склад - поле діяльності для формування та змін культури організації. Остання має бути забезпечена різними видами ресурсів для стабільного функціонування, брак ресурсу спричиняє проблеми у роботі, які можуть мати негативні наслідки для організації в цілому. 
Брак людського ресурсу може унеможливити передачу ціннісних орієнтацій i зруйнувати організаційну культуру.

Фактори зовнішнього та внутрішнього середовища безпосередньо або опосередковано впливають на діяльність організації, що, у свою чергу, формує ОК підприємства. До цих факторів можна віднести: національну культуру, акціонерів та власників, ділових партнерів, внутрішню ситуацію в країні, науково-технічний прогрес, сферу діяльності підприємства, особистість засновника, рівень освіти та кваліфікації працівника, стадію життєвого циклу організації, іiї розмір, технологію виробництва. Серед сукупності факторів найбільший вплив мають: національна культура, особистість засновника, сфера діяльності фірми, рівень кваліфікації працівників та розмір підприємства. Дані аналізу ступеню впливу, виражені у відсотках, подано нижче (рис. 5) [15, с. 54].

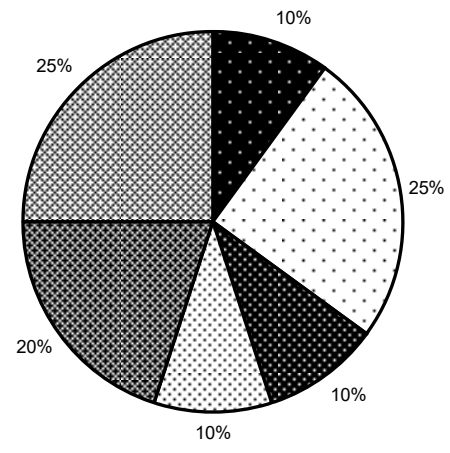

• розмір організації;

$\square$ стадія життєвого циклу;

с сфера діяльності;

굴н компетентності персоналу;

х особистість керівника;

图 національна культура * Джерело [15].

Проведений аналіз дозволяє визначити місце ОК у структурі інноваційного потенціалу підприємства.

По-перше, структура ОК та інноваційного потенціалу містить спільний елемент - мікроклімат, який передбачає створення умов, що можуть сприяти розвитку інноваційності організації.

По-друге, фактори ОК здебільшого формують структуру інноваційного потенціалу: особистість засновника визначає стиль управління, систему комунікацій; розмір організації - iї структуру, наявність різних технологічних приміщень, можливість вільного переміщення персоналу та організацію праці.

По-третє, технологія виробництва, прийнята в організації, визначає рівень іiі інноваційного потенціалу. Гнучкість ОК дозволяє інтенсивніше застосовувати та адаптувати на підприємстві інноваційні технології.

Висновки. ОК не завжди має чіткі ознаки для диференціації эї в організації, тому виникають труднощі в процесі іiі вивчення. Отже, очевидна необхідність аналізу факторів та чинників ОК обумовила основні завдання нашого дослідження. Систематизація факторів, характеристика їх впливу на культуру організації дозволяє визначити їх подальше використання для формування стабільної ОК або іiі удосконалення.

Визначено, що формування та зміна організаційної культури відбуваються під впливом первинних і вторинних факторів. Також виявлено, що на організацію взагалі ї ї̈ культуру зокрема фактори зовнішнього та внутрішнього характеру впливають по-різному. 
ОК й інноваційний потенціал мають спільні й взаємозалежні елементи. Таким чином, з'ясовано, що ОК впливає на формування й розвиток інноваційного потенціалу підприємства.

Наукова новизна дослідження. Вперше сформульовано визначення ОК як моделі ключових елементів, істинно правильної і такої, яку передають новим членам колективу як певну догму.

Практичне значення роботи полягає в узагальненні та порівнянні базових елементів ОК та інноваційного потенціалу й виявленні спільних рис, що дає можливість визначити значущість формування та розвитку організаційної культури в підвищенні інноваційності підприємства.

Подальшими завданнями визначимо аналіз впливу факторів на українські підприємства, виявлення проблем і розробку планів щодо їх усунення або попередження.

\section{Бібліографічні посилання}

1. Deal, T. E. Corporate Cultures: The Rites and Rituals of Corporate Life [Text] / T. E. Deal, A.A. Kennedy. - Reading, Mass.: Addison-Wesley Publishing Co., 1982. $232 \mathrm{p}$.

2. Schumpeter, J. Essays on entrepreneurs, innovations, business cycles, and the evolution of capitalism [Text] / J. A. Schumpeter; ed. by Richard V. Clemence; with a new introduction by Richard Swedberg. - N.Y.: -Transactions Publishers, 1989. - 461 p.

3. Андрушків, Б. М. Основи менеджменту [Текст]: монографія / Б. М. Андрушків, О. С. Кузьмін. - Л.: Світ, 1995. - 296 с.

4. Асаул, А. Н. Культура организации: проблемы формирования и управления [Электронный ресурс] / А. Н. Асаул, М. А. Асаул, П. Ю. Ерофеев, М. П. Ерофеев. - СПб.: Гуманистика, 2006. - Режим доступа: http://www.aup.ru/ books/m12/2_2.htm\#_ftnref20 - Загл. с экрана.

5. Друкер, П. Ф. Менеджмент [Текст] : пер. с англ. / П. Ф. Друкер, Д. А. Макьярелло - М.: ООО «И. Д. Вильямс», 2010. - 704 с.

6. Захарчин, Г.М. Механізм формування організаційної культури машинобудівного підприємства [Текст]: монографія. / Г. М. Захарчин - Л: Вид-во Нац. ун-ту «Львів. політехніка», 2009. - 276 с.

7. Капитонов, Э. А. Корпоративная культура:теория и практика [Текст] / Э.А. Капитонов, Г.П. Зинченко, А.Э. Капитонов. - М.: Альфа-Пресс, 2005. - 352 с.

8. Комплекс методик для вивчення особливостей та детермінант розвитку організаційної культури освітніх організацій [Текст] / Л. М. Карамушка [та ін.] // Актуальні проблеми психології: зб. наук. пр. Ін-ту психології ім. Г.С. Костюка НАПН України / [редкол. : С.Д. Максименко (гол. ред.) [та ін.]]. - Алчевськ, : 2014. - Т. I : Організаційна психологія. Економічна психологія. Соціальна психологія . 2014. - Вип. 40. - С. 9-15.

9. Кириченко, В. В. Особенности восприятия организационной культуры персоналом промышленного предприятия [Текст] / В.В. Кириченко, А. П. Крупский // Вісн. Харків. ун-ту. Сер.: Психологія. - 2004. - № 617. - С. 55-60.

10. Краснокутська, Н. С. Потенціал підприємства: формування та оцінка [Текст]: [навч. посіб.] / Н. С. Краснокутська. - К.: Центр навч. літ-ри, 2005. - 352 с.

11. Крупський, О. П. Процес формування і розвитку організаційної культури туристичних підприємств [Текст] / О. П. Крупський // Управління розвитком підприємства в інтеграційних умовах: колект. монографія / за заг. ред. Т. В. Гринько. - Д., 2014. - С. 162-177. 
12. Ландик, В. І. Управление инновационным потенциалом предприятия в условиях переходной экономики: проблемы и опыт [Текст] / В. І. Ландик // Экономист. - 2001. - № 12. - С. 52-57.

13. Льюис, P. Деловые культуры в международном бизнесе [Текст] / Р. Льюис. - М.: Дело, 2001. - 448 с.

14. Мескон, М. Основы менеджмента: пер. с англ. / М. Мескон, М. Альберт, Ф. Хедоури; под. ред. Л.И. Евенко. - М.: Дело, 1997 - 493 с.

15. Тихомирова, О. Г. Организационная культура: формирование, развитие и оценка [Текст] / О.Г.Тихомирова. - СПб.: ИТМО, 2008. - 154 с.

16. Усачева, В. В. Организационная культура в транзитивной экономике: политэкономический аспект [Текст]: дис. ... канд. экон. наук: 08.01.01 / Усачева Вероника Валериевна. - Донецк, 2003. - 172 с.

17. Харчишина, О. В. Формування організаційної культури в системі менеджменту підприємств харчової промисловості [Текст]: монографія / О. В. Харчишина. - Житомир: Вид-во ЖДУ ім. І. Франка, 2011. -290 с.

18. Шейн, Э. Х. Организационная культура и лидерство [Текст] / Э.Х. Шейн; пер. с англ.; под ред. В. А. Спивака. - СПб.: Питер, 2002. - 336 с.

19. Шморган, Л. Г. Зовнішнє середовище організації. Державне регулювання як один із головних чинників впливу зовнішнього середовища [Електронний pecypc] / Л.Г.Шморган. - Режим доступу: http://pidruchniki.com/10561127/ menedzhment/zovnishnye_seredovische_organizatsiyi_derzhavne_regulyuvannya_chinni k_vplivu - Заголовок з екрана.

Надійшла до редколегї̈ 14.11.15

УДК 339.9[338.3:330.341.1](73+52)

Т. В. Климова

Днепропетровский национальный университет имени Олеся Гончара, Украина

\section{СРАВНИТЕЛЬНАЯ ХАРАКТЕРИСТИКА СТАНОВЛЕНИЯ ИННОВАЦИОННОЙ ПОЛИТИКИ США И ЯПОНИИ}

Проанализировано становление инновационной политики США и Японии. На основе современных статистических данных сделана попытка системно оценить значение развития инновационной деятельности для экономик США и Японии. Определены общие черты и различия становления инновационной деятельности этих стран. Разработана схема создания инновационной инфраструктуры в странах с развивающейся экономикой.

Ключевые слова: венчурные фирмы, инновации, внедрения инноваций, коммерциализация, технопарк, бизнес-инкубатор.

Проаналізовано становлення інноваційної політики США і Японії. На основі сучасних статистичних даних системно оцінено значення розвитку інноваційної діяльності для економік США і Японії. Визначено загальні риси і відмінності становлення інноваційної діяльності цих країн. Розроблено схему розвитку інноваційної політики в розвинених економіках світу.

Ключові слова: венчурні фірми, інновації, упровадження інновацій, комерціалізація, технопарк, бізнес-інкубатор.

(C) Климова Т. В., 2015 